\title{
Effectiveness of Genetic Module to Reduce Misconception Levels and Improve Cognitive Learning Outcomes of Grade XII Students of SMA Negeri 5 Malang
}

\author{
Didik Dwi Prastyo a , Mohamad Amin ${ }^{\text {b, * , Hendra Susanto }}{ }^{\text {c }}$ \\ ${ }^{a}$ Postgraduate Program Department of Biology, Faculty of Mathematics and Natural Sciences, \\ Universitas Negeri Malang \\ ${ }^{b, c}$ Department of Biology, Faculty of Mathematics and Natural Sciences, \\ Universitas Negeri Malang \\ Semarang Street, Number 5, Malang, East Java, Indonesia
}

*Corresponding author's e-mail: mohamad.amin.fmipa@um.ac.id

\begin{abstract}
We investigate the effectiveness of module to reduce misconception and improve learning outcomes in genetic material using multiple choice test with CRI. This study using pre-experiment study with one group pretest post test design. This study reports the results of analysis of misconception level of XII grades in SMA Negeri 5 Malang reduce from 33,42\% to 12.92\%. Learning outcome increase from 38.30 into 72,96 . These results indicate that the genetic module is effective to reducing the level of misconceptions and improving student cognitive learning outcomes.
\end{abstract}

Keywords: Misconception, learning outcomes, genetic

\section{Introduction}

Education in Indonesia is never separated from the problems. One of the problems that until now there are still many obstacles that hinder the advancement of education in Indonesia, namely from the infrastructure that is not evenly distributed throughout the region, the new student admission system which until now has become a polemic in society, to the low understanding of concepts in students. Concept understanding will be a serious problem if it is not addressed immediately, because if students' understanding of concepts is low, further learning will be hampered [1].

Biology is a branch of science in which students' understanding of concepts is still low. This happens because science is a subject which contains concepts, facts, principles, and methods that follow a scientific framework of thinking about a phenomenon that exists in nature, and is definite, 
so that when a misconception occurs it will affect the material to be taught in the following materials, because science has a hierarchy of sciences arranged in order from simple to complex phenomena. The material in science also cannot stand alone, so it must be integrated between scientific disciplines so that it can solve phenomena that exist in nature because they are interrelated and cannot be separated from one another [2]. Biology is a part of science where the students' understanding of concepts is quite low and also many students experience errors in grasping the right concept or commonly known as misconceptions [3] [4].

Misconceptions are not simple things that are easily ignored in the learning process. Misconceptions can hinder the subsequent learning process, because the concepts between materials in Biology are integrated with each other [5]. Misconceptions are also dangerous because the material that is embedded in students is difficult to change, unless students consciously want to change it [6]. In general, misconceptions can come from the experiences of students, teachers, books studied, context, and learning methods used [7].

Genetics is a material in biology that has many misconceptions. This happens because many foreign terms are similar and foreign to students. Learning genetics in schools should be able to provide learning that can make students understand the concept of genetics as a whole, but there are many problems with learning genetics. Many research stated that students considered genetics lessons tiring and boring [8]. Students find it difficult to understand the concept of genetics because it is abstract to them and far from everyday life. Students are not able to fully construct genetics and students are unable to connect the concepts of genetics. This is also supported by other research conducted at SMA Negeri 13 Medan which shows that there is a misconception in Genetics material by $32.01 \%$. The sub-material that experienced the most misconceptions was protein synthesis with a misconception level of $38.54 \%$ [9], other study conducted a study on Biology students at UNTIRTA showing that out of 53 students who were research objects, $21.16 \%$ of students experienced misconceptions while the rest $64.02 \%$ knew the concept and $14.82 \%$ did not know the concept. The highest percentage of misconceptions was found in the sub-concept of the mechanism of protein synthesis (25\%) and followed by the sub-concept of gene organization structure (24.53\%) [10].

Misconceptions can also result in decreased student learning outcomes. This happens because students feel that what they believe in their mind is the right thing, even though it is not in accordance with the opinions of experts [11]. This is also in accordance with the results of preliminary research which resulted that more than $70 \%$ of students scored below the standards given by the school (KKM). So that learning is needed that can improve student learning outcomes. 
The results of the needs analysis also showed that students needed teaching materials in the form of modules with a percentage at 57\%. Modules are teaching materials that are systematically designed based on a certain curriculum and are packaged in the smallest learning unit and allow them to be studied independently in a certain time unit so that students master the competencies being taught. The learning module according to is the smallest unit of teaching and learning programs, which students learn individually or are taught by students to themselves (selfinstructional) [12]. The module to be made must be able to make lower the level of student misconceptions and also improve student learning outcomes, so that the module to be developed contains learning syntax that can accommodate learning that students can use to be able to build their knowledge properly. Other studies on misconceptions only find out the level of misconceptions, and only develop modules, not much has shown the effectiveness of the modules made. Based on the background, a research was conducted with the title "Effectiveness Genetics Module to Reduce Levels of Misconception and Improve Learning Outcomes of Class XII Students of SMA Negeri 5 Malang".

\section{Method}

The research aimed to testing the effectiveness of module to reduce misconception and improve learning outcomes in genetic material. This research is a pre-experiment study with one group pretest post test design. Before the research was carried out, module development was carried out by referring to the research and development (R\&D) method, namely ADDIE by Branch (2009). The population in this study were students of class XII who had taken genetic material in high school, while the sample used was 32 students. The instrument used was a multiple choice test equipped with a CRI questionnaire which aims to determine the level of student misconceptions on genetic material that has been validated by experts and tested the questions using empirical tests. The data used were pretest and posttest data, which then calculated the difference using the paired test and normalized gain ( $\mathrm{N}$ gain) formula with the help of SPSS 25.0 for Windows with a significance level of 0.05 .

\section{Results and Discussion}

\section{a. Level Misconception After Using Genetic Module}

The results of the implementation are used to determine the effectiveness of the product developed on the level of misconceptions in students. The effectiveness of the module is tested by comparing the results of the pretest and posttest which are then tested with a paired t-test to find out the difference between the pretest and posttest results after using the module, then the calculation of 
the module effectiveness level is carried out using the $\mathrm{N}$ gain formula. The result pretest and posttest can be seen in table 1 .

Table 1.

Result of level Misconception

\begin{tabular}{lll}
\hline Basic Competence & Pre test $(\%)$ & Post test $(\%)$ \\
\hline 3.3 & 31.66 & 13 \\
3.4 & 44 & 14.31 \\
3.5 & 26.73 & 6.83 \\
3.6 & 28.38 & 8.63 \\
3.7 & 27.42 & 15.2 \\
3.8 & 37.9 & 19.5 \\
\hline Average & $\mathbf{3 3 , 4 2}$ & $\mathbf{1 2 , 9 2}$ \\
\hline
\end{tabular}

The paired t-test results showed a difference in the level of misconception between before using the module and after with the results of $t$ count $(8.287)>t$ table (1.657), which means that H0 is rejected, so it is concluded that there is a difference in the level of student misconception before and after the module is used. Then proceed to measure the level of effectiveness of the module to reduce the level of misconceptions using the $\mathrm{N}$ gain formula. The results of the calculation show a result of 0.604, when compared with the criteria, the moduk is said to have a moderate level of effectiveness, which means that the module is effective enough to reduce the level of misconceptions in students.

b. Cognitive Learning Outcomes

Analysis the different of cognitive learning outcomes is carried out by looking at the differences between pretest and posttest. The difference between the pretest and posttest results was analyzed using Normalized-gain. The results of the analysis can be seen in table 2 .

Table 2.

The Result Cognitive Learning Outcomes

\begin{tabular}{llll}
\hline Pre test $(\boldsymbol{\%})$ & Post test $\mathbf{\%})$ & N-Gain & Categori \\
\hline 38.30 & 72.96 & 0,6 & moderate \\
\hline
\end{tabular}


The t-test which was conducted to determine the differences in students' cognitive learning outcomes before and after using the module got the results of tcount (6.840)> $t$ table (1.279). The conclusion that can be drawn is that there are differences in student cognitive learning outcomes before and after using the developed module. Next, it is followed by measuring the effectiveness of the module on students' cognitive learning outcomes using a module with the $\mathrm{N}$ gain formula. The results of the calculation show a result of 0.571 , if converted to the existing criteria the module being developed has a moderate level of module effectiveness, so it can be said that the module is effective enough to improve cognitive learning outcomes of class XII students

The results of the analysis of misconceptions in students from the pretest results showed that the level of understanding of the concepts in SMA Negeri 5 Malang on genetics material was quite low. This is supported by the results of the misconception identification test, with details of students who understand the concept, only $39.27 \%$ of students understand the concept, $33.42 \%$ of students experience misconceptions, and $27.25 \%$ of students do not understand the concept. The results of this test indicate that there is something wrong with the learning carried out by the students, so there are several items where most students experience misconceptions.

The items with the highest misconception level were question number 14 , namely $84 \%$ of students experienced misconceptions on these items. This question asks about spermatogenesis. Only one student who correctly answered this question. When looking for the CRIs value in this number, the value is 3.40 (> 2.5), so it can be concluded that on this item, students experience misconceptions on the concept of sprematogenesis.

Spermatogenesis is a concept covered in cell division material, namely KD 3.4. This concept is quite a complex concept, because there are stages in the process of development and division of the spermatogonia cells to become active spermatozoa. This is due to students misinterpreting the concept because of some of the books used by students misrepresenting and also the teacher is not accurate in explaining the spermatogenesis process. The misinterpretation occurs because students think that every single spermatogonia will always produce four active spermatozoa, even though in the process the spermatogonia does not always grow into spermatocytes, but can still divide mitosis to produce another spermatogonia, so that each spermatozoa has the possibility to produce more than four spermatozoa. active [13].

The problem with the biggest misconception value is question number 11, in this question students are asked to explain the process of mitotic division in living things, namely the process that 
occurs in the interphase phase. Many students get stuck with answering resting cells. This may occur due to misrepresenting what is in the book. One of the books states that the interphase phase is a resting phase, which means that the cell does not carry out physical or chemical activity, so that students assume that the cell is not doing anything, even though the interphase phase is a very important phase, because in that phase the cell is growing and synthesizing DNA. will be used for the cleavage process [14].

This developed module has a distinctive feature, namely that there are several discussions about misconceptions that must be left by students, both those obtained from previous education levels, from books used for learning, and teachers who experience misconceptions. The discussion is used to reduce and also minimize the occurrence of misconceptions in students. Another characteristic of this module is constructivist learning in which students explore their own knowledge wrapped in a guided inquiry learning model syntax which requires students to seek their own knowledge. Research show that learning using inquiry can hinder the occurrence of misconceptions in students, because students focus on digging up information, not just remembering bits of information as is done through conventional learning. Other studies have also concluded that guided inquiry can overcome misconceptions [15]. Inquiry can be carried out by exposing facts to a phenomenon that is contrary to the initial concept of students (cognitive conflict), so that because of differences in understanding between those conveyed by existing phenomena and students' understanding, students are able to make students more motivated to explore knowledge or information [6-18].

The decrease in the level of misconceptions was due to the module being developed based on the results of the respondent's initial test analysis, so that the concepts that became misconceptions before using the module could be overcome by the existence of this developed module, besides that the developed module also had a representative and attractive image, so that the respondents become more interested in learning using modules that have been developed. This is in accordance with the opinion stated that the use of modules that have attractive images can increase motivation, response and student learning outcomes to be better, also strengthened by other study which states that modules are more effective used to reduce misconceptions compared to conventional textbooks [19].

Understanding the concept of students will be good if the concepts that exist in students are well and correctly embedded, after students understand the concepts that exist in themselves then students can link the relationship between concepts, not just memorizing concepts, so that when the concepts are understood then students It will be easy to link the relationship between the concepts that exist in the learning process [20], so that if the teaching materials used by students are good and correct, the understanding of the concepts in students will increase. 
The results of the calculation using the N-gain formula for cognitive learning outcomes of students get a result of 0.57 , which is on moderate criteria. This shows that the module developed is effective enough to improve student cognitive learning outcomes. The pretest mean result of the students showed a result of 48.6 which increased to 73.6 after the use of the developed module. This happens because the module developed uses an inquiry learning philosophy, where students build their own knowledge by finding out the information that is being studied. This is in accordance with the other opinion which states that learning using the inquiry model is more effective than using the traditional model, because in traditional learning students only focus on getting the right answer rather than the process of getting information [21,22]. The developed module also has an attractive and representative image, this also helps students to construct their own knowledge rather than only using books that do not have pictures or only text, because students find it difficult to understand information because they do not feel the learning themselves so that student learning outcomes less than optimal [23].

\section{Summary}

The conclusion of this study is that Genetics modules is effective to reduce the level of misconception from 33.42 to 12.92 , and improve cognitive learning outcomes from 38.30 to 72.96 .

\section{Acknowledgment}

We thank to SMA Negeri 5 Malang, who provided place and facilities for this research.

\section{References}

[1] Laksana DNL. Miskonsepsi Dalam Materi Ipa Sekolah Dasar. JPI (Jurnal Pendidik Indones. 2016;5(2):166.

[2] Barrass R. Some misconceptions and misunderstandings perpetuated by teachers and textbooks of biology. J Biol Educ. 1984;18(3):201-6.

[3] Liliawati W, Ramalis TR. Identifikasi Miskonsepsi Materi IPBA di SMA Dengan Menggunakan CRI (Certainly of Respons Index) Dalam Upaya Perbaikan Urutan Pemberian Materi IPBA Pada KTSP. Pros Semin Nas Penelitian, Pendidikan, dan Penerapan MIPA. 2009;159-68.

[4] Tanziah, Lia Li'anatus; Rachamdiarti, Fida; Prastiwi MS. BioEdu BioEdu. 2016;5(3):189-93.

[5] Yip D-Y (Departement of curriculum and instruction TCU of HK. Identification of misconceptions in novice biology teachers and remedial strategies for improving biology learning. Int J Sci Educ. 1998;20(4):37-41. 
[6] Goff EE, Reindl KM, Johnson C, McClean P, Offerdahl EG, Schroeder NL, et al. Efficacy of a Meiosis Learning Module Developed for the Virtual Cell Animation Collection. Allen D, editor. CBE_Life Sci Educ. 2017 Mar;16(1):ar9.

[7] Hong Kwen B. Teachers ' Misconceptions of Biological Science Concepts as Revealed in Science Examination Papers. Int Educ Res Conf. 2005;(December):1-8.

[8] Venville, E. J. And Treagust DF. venville dan Treagust. Aust Sci Teach J. 2002;48(2):20-4.

[9] Sarhim FP, Harahap F. Identifikasi Miskonsepsi Siswa Pada Materi Genetika Di Kelas XII IPA SMA Negeri 13 Medan Tahun Pembelajaran 2014 / 2015. J Pelita Pendidik. 2015;3(4):162-70.

[10] Murni D. Identifikasi Miskonsepsi Mahasiswa Pada Konsep Substansi Genetika Menggunakan Certainty of Response Index (CRI). Pros Semirata FMIPA Univ Lampung. 2013;1(1):205-12.

[11] Chaniariosi LF. Identifikasi Miskonsepsi Guru Biologi Sma Kelas Xi Ipa Pada Konsep Sistem Reproduksi Manusia. J EduBio Trop. 2015;2(2):187-91.

[12] Weaver G, Russell C, Wink D. Inquiry-based and research-based laboratory pedagogies in undergraduate science. Nat Chem Biol 4. 2008;(577-580).

[13] Reece JB, Urry LA, Cain ML, Wasserman SA, Minorsky P V., Jackson RB. Campbell Biology. Campbell Biology. 2010.

[14] Russel P j. i Genetic Mollecular Approach. 3Th ed. Vol. 53. New York: Benjamin Cummings; 2019. 1689-1699 p.

[15] Longfield J. Discrepant Teaching Events: Using an Inquiry Stance to Address Students' Misconceptions. Int J Teach Learn High Educ [Internet]. 2009;21(2):266-71. Available from: http://www.isetl.org/ijtlhe/

[16] Hasanah N, Hidayat A, H SK. Pengaruh Pendekatan Konflik Kognitif melalui Model Pembelajaran Guided Inquiry untuk Mengurangi Miskonsepsi Siswa pada Materi Gelombang Mekanik. Pros Semin Pend IPA Pascasarj UM. 2017;2:239-46.

[17] Zulia Witanecahya S, Jatmiko B. Penerapan Model Pembelajaran Inkuiri Terbimbing (Guided Inquiry) untuk Mengurangi Miskonsepsi Siswa Kelas X SMAN 2 Ponorogo pada Pokok Bahasan Perpindahan Panas. J Inov Pendidik Fis. 2014;03(03):6-10.

[18] Zuhri MS, Jatmiko B, Fisika J, Surabaya UN, Simulation P. Penerapan Model Pembelajaran Inkuiri (Inquiry Learning) Menggunakan Phet Simulation Untuk Menurunkan Miskonsepsi Siswa XI Pada Materi Fluida Statis Di SMAN Kesamben Jombang. J Inov Pendidik Fis. 2014;03(03):103-7.

[19] Grospietsch F, Mayer J. Professionalizing pre-service biology teachers' misconceptions about learning and the brain through conceptual change. Educ Sci. 2018;8(3):1-23. 
[20] Wenno IH, Esomar K, Sopacua V. Analisis Kesulitan Belajar Dan Pencapaian Hasil Belajar Siswa Melalui Strategi Pembelajaran Inkuiri. J Cakrawala Pendidik. 2016;35(3):378-85.

[21] Barrow LH. A brief history of inquiry: From dewey to standards. J Sci Teacher Educ. 2006;17(3):265-78.

[22] Bunterm T, Lee K, Ng Lan Kong J, Srikoon S, Vangpoomyai P, Rattanavongsa J, et al. Do Different Levels of Inquiry Lead to Different Learning Outcomes? A comparison between guided and structured inquiry. Int J Sci Educ [Internet]. 2014;36(12):1937-59. Available from: http://dx.doi.org/10.1080/09500693.2014.886347

[23] Fitriani NR, Widiyatmoko A, Khusniati M. The effectiveness of CTL model guided inquiri-based in the topic of chemicals in daily life to improve students' learning outcomes and activeness. J Pendidik IPA Indones. 2016;5(2):278-83. 